ORIGINAL ARTICLE

\title{
Predicting spatial distribution patterns and hotspots of fish assemblage in a coastal basin of the central-south of Chile, by geostatistical techniques
}

\author{
Sam CATCHPOLE,,${ }^{1,2}$ Reinaldo RIVERA, ${ }^{3 *}$ Cristián E. HERNÁNDEZ, ${ }^{3}$ Javiera DE LA PEÑA, ${ }^{2}$ Pablo GONZÁLEZ ${ }^{4}$ \\ ${ }^{1}$ Fundación Organización para el Desarrollo y la Sustentabilidad (ODyS), Concepción; ${ }^{2}$ Pares \& Álvarez Gestión Ambiental, \\ Concepción; ${ }^{3}$ Laboratorio de Ecología Evolutiva y Filoinformática, Facultad de Ciencias Naturales y Oceanográficas, Departamento \\ de Zoología, Universidad de Concepción; ${ }^{4}$ Centro Regional de Estudios Ambientales (C.R.E.A), Universidad Católica de la \\ Santísima Concepción, Concepción, Chile
}

\begin{abstract}
Currently the application of geographic information systems in the subjects of biology and ecology has facilitated the study patterns of distribution, richness and diversity of species. However, in freshwater ecosystems the application of geostatistical analysis are scarcely used in the worldwide, including Chile. Therefore, in our study we developed predictive maps using simple Kriging (resolution $12.5 \mathrm{x}$ $12.5 \mathrm{~m}$ ), based on richness and Shannon-Weaver diversity, and we analyzed spatial autocorrelation of fish assemblages (Moran and Getis-Ord index) present in the Andalién River basin. Our results established a fish assemblage composition of 24 species, most of them native $(79 \%)$ and with endanger conservation status. Predictive maps showed highest values of richness and diversity of fish species in the potamon zone of the Andalién and Nonguén streams, while the low values were described in the Chaimavida sub-basin and the transition zone of Andalién River. The Moran and Getis-Ord index determined a cluster pattern of the data and define hotspot and coldspot zones, concordant with the predictive maps of richness and Shannon-Weaver diversity. The geostatistical and spatial techniques showed to be relevant tools for the determination of distribution patterns of freshwater species and conservation issues.
\end{abstract}

\section{INTRODUCTION}

The macroecology and biodiversity data show strong spatial patterns, structured as a function of biological processes and usually autocorrelated (Legendre, 1993; Rangel et al., 2006). These structure patterns that govern ecology and biogeography are influenced and correlated with variables such as richness, diversity of species (Fortin and Dale, 2005) and environment configuration (Rangel et al., 2006). These ecological variables sampled and mapped by the application of geographic information system are relevant to determine actions and decisions on conservation issues of protected areas, biological corridors, distribution of endemic species, richness patterns, hotspot, indicator species and mitigate or

Corresponding author: reijavier@gmail.com

Key words: Kriging; interpolation; spatial autocorrelation; Andalién River basin.

Edited by: Pietro Volta, CNR-IRSA Verbania, Italy

Received: 10 December 2018

Accepted: 3 April 2019.

This work is licensed under a Creative Commons Attribution NonCommercial 4.0 License (CC BY-NC 4.0).

${ }^{\circ}$ Copyright: the Author(s), 2019

Licensee PAGEPress, Italy

J. Limnol., 2019; 78(2): 220-232

DOI: 10.4081/jlimnol.2019.1881 minimize environmental impacts (Carroll and Pearson, 2000; Williams et al., 2002).

Geostatistics is a key tool to predict and quantify the scale of spatial variation between different species and their spatial distribution. Further, geostatistics is important to understand ecological processes that occur at different spatio-temporal scales, for example, the relationship between species diversity and spatial heterogeneity (Gallardo, 2006).

Matheron in 1963 described the geostatistic term as the application of the formalism of random functions to recognition and estimation of natural phenomena. The origins of the geostatistic techniques are related to geologic disciplines and mining industry (Cressie, 1985; 1990) and applied to continuous spatial data. These techniques range from those used to model spatial relationships (Aubry and Debouzie, 2000) to those used to make optimal predictions (e.g. richness of species) at unsampled sites (Carroll and Pearson, 1998). Kriging, one of the most popular geostatistic techniques, has been defined as "a method of interpolation for random spatial" (Ord, 1983). While, Hemyari and Nofziger (1987) describes as a "form of weighted averaging in which the weights are chosen such that the error associated with the predictor is less than for any other linear sum.... The weights depend upon the location of the points used in the prediction process and upon the covariation... reflected in the semivariogram". More recently, this analysis is defined as an interpolation method based in a stochastic spatial variation model that fits well to the reality (Oliver and Webster, 1990), founded on the minimization of the mean standardize error with the prediction (variogram) (Armstrong et al., 1992; Cruz-Cárdenas et al., 2013). The 
hypothesis of the kriging method establishes the fact that spatial variations of the object or study variable are statistically homogeneous over a specific location (Krige, 1951; Isaaks and Srivastava, 1989). Therefore, it is essential to determine the spatial autocorrelation of the object or study variable (Rivoirard et al., 2000), described as patterns of spatial continuity and dependence (Goodchild, 1987; Carroll and Pearson, 1998) which confirms the Tobbler principle (Ramírez and Falcón, 2015).

Many studies have been performed using spatial interpolation methods (e.g. kriging group) to establish richness and diversity on vascular flora (Kreft and Jetz, 2007; Hernández-Pérez et al., 2011; Cruz-Cárdenas et al., 2013), brown algae (Hernández-Cervantes et al., 2014), insects (Ballesteros-Mejia et al., 2013), birds (Lin et al., 2008), reptiles (Martínez-Freiría et al., 2009; Martínez and Brito, 2013) amphibians (Reeves et al., 2013), marine fishes (Petitgas, 1992; Ayala-Pérez et al., 2001; Ortiz, 2013), crustaceans (Ruiz-Luna et al., 2010; Ferreira et al., 2016), marine mammals (Monestiez et al., 2006) and fauna in general (Martinez, 2015). But in freshwater fish have been little or no attention, even when this group is relevant as bioindicators of quality water and key species for riverine trophic webs (Northcote, 1988; Parkos et al., 2003). Nevertheless, in fluvial systems, spatial distribution models in freshwater fish have been developed using environmental variables as predictors that determine the structure and spatial composition of fish assemblages. For instance, hydraulic conditions (Marchetti and Moyle, 2001), substratum type (Humpl and Pivnicka, 2006), natural barriers (Rahel, 2007), physicochemical conditions (Matthews, 1998; Buisson et al., 2008) and riparian vegetation (Growns et al., 2003).

Based on the scarce application of geostatistics in freshwater systems as a predictive tool for spatial distribution patterns of ichthyofauna is that this study evaluates patterns of spatial in a coastal central-south basin off Chile. First, we determinate the species richness and diversity for each tributary stream. Second, we performed a kriging interpolation based on both index evaluating almost all the basin, and identify cluster grouping and hotspot/coldspot using general Moran's index and Gi* Getis-Ord along the basin.

\section{METHODS}

\section{Study area}

The Andalién River basin was defined as the study area, a fourth order basin, situated in the central-south off Chile, specifically on the coastal mountain range, which covers a drainage area of $775 \mathrm{~km}^{2}$ (Jaque, 1996). The Andalién River is born from the union of the Poñén and Curapalihue streams, at a sector called "Puente Siete", presenting a high sinuosity on rithron and transition zone, while the potamon stretch is an alluvial plain, bordering the city of Concepción. The hydrologic regimen is pluvial, with an average annual flow of $14.3 \mathrm{~m}^{3} / \mathrm{s}$, showing minimal flows in the summer $\left(10 \mathrm{~m}^{3} / \mathrm{s}\right)$ and maximal flow levels in winter $\left(1500 \mathrm{~m}^{3} / \mathrm{s}\right)$ (Jaque, 2008).

Sixty-two (62) sampling sites were analysed along the basin, spatially distributed in the different riverine zones (rithron, transition and potamon). Geographical location of each sampling site was determined by a Garmin GPS, model Montana 650, using Universal Transverse Mercator Projection (UTM, WGS 84 19S). The distribution of the sampling sites between the zones was developed in the following way: thirty-six (36) sites located on potamon zone, nine (9) sites on the transition and seventeen (17) sites correspond to the rithron zone (Fig. 1). A brief description of the physicochemical characteristics of the rithron, transition and potamon zones are described in Tab. 1 .

\section{Ecological index}

The species richness and Shannon-Weaver diversity estimation was obtained from the data base of fisheries investigations provided by the Government Department of Fisheries and Aquaculture of Chile (SUBPESCA, in Spanish), a review and compilation of freshwater researches (scientific and technical capture reports) and personal fish sampling performed with standardized electrofishing methods along the Andalién River basin.

A data of 10,545 captures freshwater fish was collected, and a maximal richness of 24 species were identified in the Andalién network. Shannon-Weaver diversity was performed using the following equation.

$H^{\prime}=\sum p i \log _{2} p i$

where $p_{i}$ is the percentage of the individuals represented by the species $i$ and is estimated by $\mathrm{N}_{\mathrm{i}} / \mathrm{N}, \mathrm{N}_{\mathrm{i}}$ is the number of individuals of a species and $\mathrm{N}$ is the total number of individuals.

To determine significant differences between the ecological index and the different zones a Kruskal-Wallis test was used, a rank-based nonparametric test which null hypothesis describes the median equality between two or more groups (Kruskal and Wallis, 1952). If significant differences came up between the groups, a Dunn's multiple comparison test was performed to recognise the different groups, using software PAST ver. 3.19 (Hammer et al., 2001).

\section{Structural variables and spatial predictions}

To achieve the three-dimensional model and the construction of the networks of Andalién basin, satellite photos where used from the Alaska Satellite Facility 
platform (https://www.asf.alaska.edu/) processed with ArcGis 10.5 software by the module ArcHydro tools and Hydrology. These photos were taken in 2011, correspond to the ALOS satellite by the PALSAR sensor (Phased Array Type L-band Synthetic Aperture Radar) with a $12.5 \mathrm{~m}$ spatial resolution. Once the photos were processed, a Digital Elevation Model (DEM) is obtained for the Andalién River basin. From the DEM, structural variables are estimated; elevation, slope and Strahler order for each site and stream sampled. The stream order was used as a proxy for habitat size and heterogeneity (Ferreira et al., 2016).

To describe the relationship between the ecological index and each structural variable (i.e. elevation, slope and Strahler order) defined as an explanatory variable, we performed the multiple regression analysis, using a stepwise procedure for selection of the most important structural predictors (Quinn and Keough, 2002).

\section{Interpolation models}

To estimate spatial distribution maps of fish assemblage based on both ecological index we applied kriging interpolation using the Geostatistical analysis extension of ARCGIS 10.6 (ESRI, 2014). The mathematical formulation is established on variograms with weight functions, which express the spatial variation (Oliver and Webster, 1990) and autocorrelation data (Robertson, 1987).

$\widehat{y}(h)=\frac{1}{2 n(h)} \sum_{i=1}^{n(h)}\left[Z\left(x_{i}\right)-Z\left(x_{i}+h\right)\right]^{2}$

Where $\left(x_{i}\right)$ and $\left(x_{i}+h\right)$ are sampling sites separated by the lag h, and $z\left(x_{i}\right)$ and $z\left(x_{i}+h\right)$ are the values of $Z$ observations (richness, and Shannon-Weaver index) for each site; and $n(h)$ represents the number of pairs sep rated by the lag distance $h$.

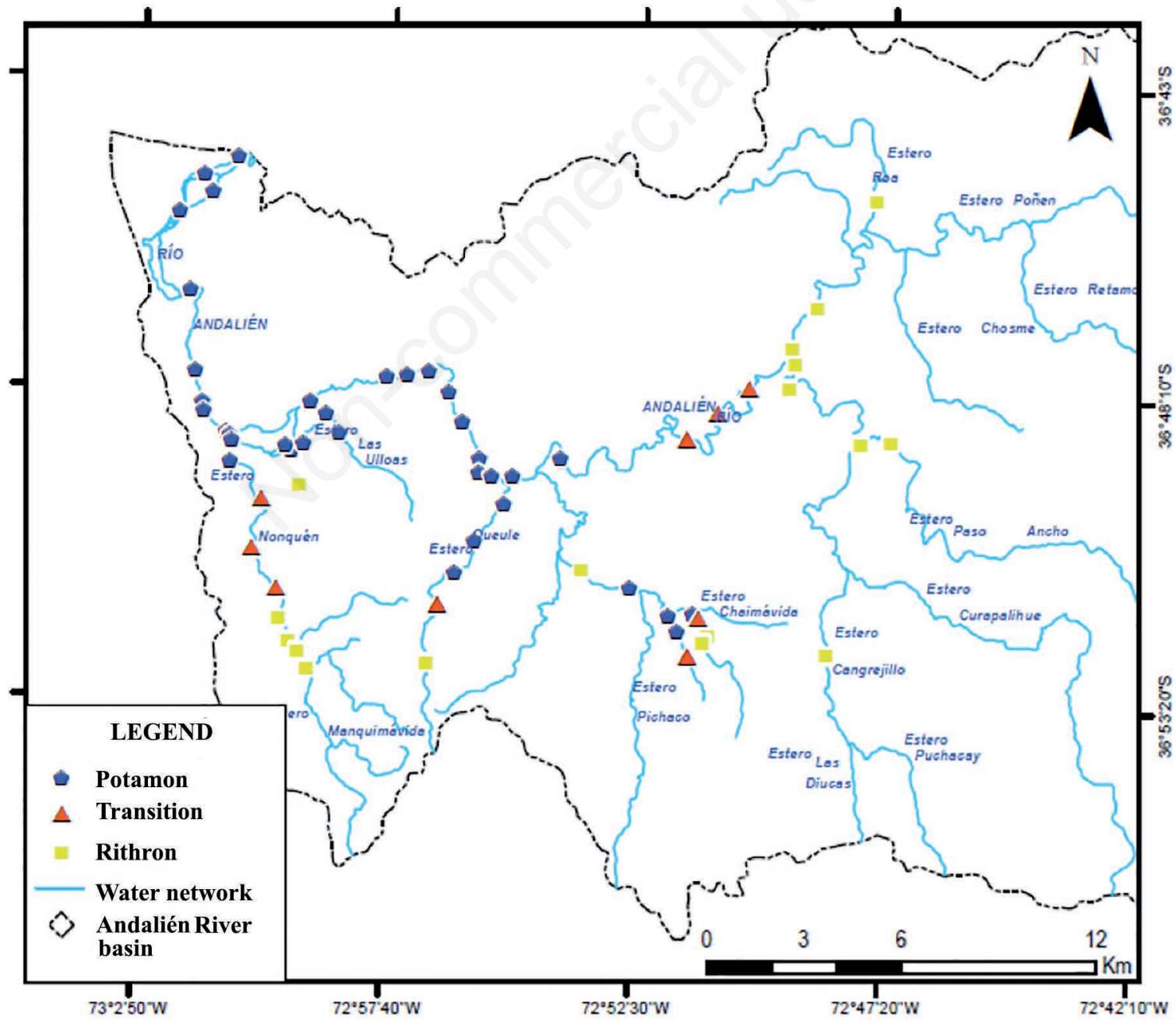

Fig. 1. Sampling sites develop in the Andalién River basin, Chile. 
Then, six different models (Stable, Spherical, Circular, Gaussian, Exponential and lineal) were evaluated to find the smallest error (Cressie, 1985). The anisotropy for each model and index was considered.

$S S E=\sum_{i=1}^{m} w_{i}[\tilde{y}-y]^{2}$

Where $m$ is number of lag (two locations separated by a determined distance), $y^{\prime}$ are the semivariance values for each distance, $y$ are the semivariance form the prediction model, and $w_{i}$ are the semivariance factors.

Three kriging methods were analysed (simple, ordinary and universal) and compared through crossvalidation, selecting the model with the lowest standardized mean of the error prediction (SMEP) (CruzCárdenas et al., 2013).

$\mathrm{SMEP}=\frac{1}{N} \sum_{i=1}^{N} \frac{M E}{\sigma^{2} x_{i}}$

Where $\mathrm{N}$ sample size, $z\left(x_{i}\right)$ is the estimated value of richness, $z\left(x_{i}\right)$ is the value of richness known and $\sigma$ is the variance of the measured values of species richness (Kravchenko and Bullock, 1999).
Once the model of interpolation was selected for each index, a buffer of $100 \mathrm{~m}$ was established for the stream network to facilitate the visualization of interpolation analysis. To developed maps of ecological index we aggregate the data to a spatial resolution of $12.5 \mathrm{~m} \times 12.5$ m UTM grid cells.

\section{Spatial patterns (hotspot and coldspot)}

Several studies have been performed to identify biodiversity hotspots (Bonn et al., 2002; Orme et al., 2005) based on multiple criteria and arbitrary conditions, but in this study we used an intuitive measure, which detects spatial clusters containing greater values of diversity and species richness than expected by chance for the study area. To determined spatial autocorrelation, we used Moran statistic index (Moran, 1950). If the results show positive and significant autocorrelation, there is clustering of high values. Negative results and autocorrelation suggests a random pattern. Then, we defined spatial hotspot using the $\mathrm{Gi}^{*}$ statistics (Getis and Ord, 1992). This index identifies spatial concentrations of an entity or areas that contain high values. To establish a statistically significant hotspot, an entity must

Tab. 1. Physicochemical and morphometric parameters of the Rithron, Transition and Potamon zones. The mean value and standard deviation are detailed. For physicochemical parameters, measurements are presented for two stations; high and low flow. Morphometric parameters are an average for the three zones (Rithron, Transition and Potamon).

\begin{tabular}{|c|c|c|c|c|c|c|c|}
\hline & \multirow[t]{2}{*}{ Unit } & \multicolumn{3}{|c|}{ High flow } & \multicolumn{3}{|c|}{ Low flow } \\
\hline & & Rithron & Transition & Potamon & Rithron & Transition & Potamon \\
\hline \multicolumn{8}{|c|}{ Physico-chemical parameters } \\
\hline Temperature & ${ }^{\circ} \mathrm{C}$ & $8.5 \pm 1.8$ & $9.0 \pm 1.8$ & $10.3 \pm 1.9$ & $10.5 \pm 3.1$ & $12.0 \pm 4.1$ & $12.8 \pm 4.2$ \\
\hline $\mathrm{pH}$ & $1-14(\mathrm{~h}+)$ & $7.7 \pm 0.3$ & $7.5 \pm 0.2$ & $7.5 \pm 0.1$ & $7.1 \pm 0.3$ & $7.1 \pm 0.3$ & $7.0 \pm 0.3$ \\
\hline Conductivity & $\mu \mathrm{s} / \mathrm{cm}$ & $72.7 \pm 14.1$ & $75.8 \pm 13.9$ & $89.8 \pm 23.1$ & $96.4 \pm 27.0$ & $101.4 \pm 31.3$ & $114.8 \pm 27.9$ \\
\hline Dissolved oxygen & $\mathrm{mg} / \mathrm{L}$ & $10.5 \pm 0.7$ & $10.3 \pm 0.5$ & $10.0 \pm 0.3$ & $11.4 \pm 0.6$ & $10.9 \pm 1.0$ & $10.6 \pm 1.0$ \\
\hline Total phosphorous & $\mathrm{mg} / \mathrm{L}$ & $0.07 \pm 0.07$ & $0.04 \pm 0.01$ & $0.1 \pm 0.05$ & $0.03 \pm 0.01$ & $0.03 \pm 0.02$ & $0.08 \pm 0.04$ \\
\hline Total nitrogen & $\mathrm{mg} / \mathrm{L}$ & $0.29 \pm 0.17$ & $0.32 \pm 0.09$ & $0.54 \pm 0.30$ & $0.28 \pm 0.10$ & $0.27 \pm 0.05$ & $0.49 \pm 0.13$ \\
\hline Total dissolved solids & $\mathrm{mg} / \mathrm{L}$ & $33.7 \pm 9.1$ & $33.7 \pm 7.4$ & $41.0 \pm 12.3$ & $37.5 \pm 9.1$ & $43.8 \pm 10.4$ & $44.2 \pm 19.1$ \\
\hline Total suspended solids & $\mathrm{mg} / \mathrm{L}$ & $11.8 \pm 8.6$ & $12.4 \pm 8.6$ & $29.1 \pm 18.7$ & $6.9 \pm 5.7$ & $6.1 \pm 4.7$ & $19.0 \pm 15.3$ \\
\hline Fecal coliforms & $\mathrm{MPN} / 100 \mathrm{~mL}$ & $228 \pm 114$ & $205 \pm 352$ & $15631 \pm 11202$ & $6283 \pm 14078$ & $332 \pm 174$ & $18840 \pm 21903$ \\
\hline Arsenic & $\mathrm{mg} / \mathrm{L}$ & - & - & $0.001 \pm 0.001$ & - & - & $0.001 \pm 0.001$ \\
\hline Boron & $\mathrm{mg} / \mathrm{L}$ & - & - & $0.3 \pm 0.4$ & - & - & $0.2 \pm 0.01$ \\
\hline Cadmium & $\mathrm{mg} / \mathrm{L}$ & $0.001 \pm 0.001$ & - & $6.8 \pm 3.0$ & $0.001 \pm 0.001$ & - & $5.6 \pm 0.6$ \\
\hline Cupper & $\mathrm{mg} / \mathrm{L}$ & $0.05 \pm 0.006$ & - & $0.015 \pm 0.01$ & $0.02 \pm 0.001$ & - & $0.016 \pm 0.01$ \\
\hline Magnesium & $\mathrm{mg} / \mathrm{L}$ & - & - & $3.1 \pm 1.2$ & - & - & $3.7 \pm 1.3$ \\
\hline Mercury & $\mathrm{mg} / \mathrm{L}$ & $0.0001 \pm 0.001$ & - & $0.001 \pm 0.001$ & $0.0001 \pm 0.001$ & - & $0.002 \pm 0.001$ \\
\hline Morphometric param & & Rithron & Transition & Potamon & & & \\
\hline Elevation & $\mathrm{m}$ & $131 \pm 46.6$ & $112.8 \pm 461.3$ & $58.2 \pm 33.9$ & & & \\
\hline Strahler strem order & number & $1.8 \pm 0.7$ & $2.3 \pm 1.0$ & $2.6 \pm 1.1$ & & & \\
\hline Slope & degree & $3.4 \pm 5.2$ & $2.6 \pm 4.0$ & $2.3 \pm 4.3$ & & & \\
\hline
\end{tabular}


have high values and be surrounded by other cells with high values. Accordingly, the local sum for an entity and its neighbors is compared proportionally with the sum of all entities. If the local sum is extremely different from the random expectation, a significant $Z$ score is assigned. Significant values of $Z>0$ provide evidence for significant hotspots whereas values of $\mathrm{Z}<0$ provide evidence for groups of entities that have lower values than expected by chance (Mitchel, 2005). The statistical determination of hotspots and coldspot was performed in ArcGis 10.3 software (ESRI, 2014).

\section{RESULTS}

\section{Fish species composition}

The ichthyofauna registered in the Andalién River basin was 24 species, belonging to 11 orders and 15 families (Ruiz, 1993; Habit and Victoriano, 2005; Habit et al., 2006; 2007) (Tab. 2). Seventy-nine percentage $(79 \%)$ of the species were native, some of them with serious conservation state (Campos et al., 1998). The richest order was represented by Perciformes with 6 species $(25 \%)$, followed by Silurifomes with 4 species (16.7\%) and Atheriniformes with 3 species (12.5\%); the remaining orders summarized 11 species $(45.8 \%)$. The analysis of species richness distribution showed a variation related with the riverine zone, revealing the highest values for the sampling sites E-6 (17 species) and E-11 (14 species) located in the potamon of Andalién and Nonguén streams, respectively. Meanwhile the lowest values of richness were reported in the Quebrada Ulloa and Chaimavida sub-basin (Las Puyas and Curapalihue tributaries) (Fig. 2).

A low global diversity was estimated for the Andalién network (1.077 $\pm 0.223 \mathrm{bit} / \mathrm{ind})$ exhibiting some picks at the sampling sites E-10 and E-12 located in the Nonguén stream, and E-7 in the Andalién stream, all of them situated in the potamon zone. Whereas Chaimavida subbasin showed lowest diversity values (Las Puyas and Curapalihue tributaries) (Fig. 3).

Additionally, fish assemblage composition (richness and diversity) for each stream showed significant differences between the tributaries and streams of the Andalién network (Tab. 3).

Tab. 2. List of fish species identified in the Andalién River basin.

\begin{tabular}{|c|c|c|}
\hline Order & Family & Species \\
\hline \multirow[t]{2}{*}{ Petromyzontidae } & Petromyzontidae & Mordacia lapicida Gray 1851 \\
\hline & Geotriidae & Geotria australis Gary 1851 \\
\hline Characiformes & Characidae & Cheiron galusdae Eigenmann 1928 \\
\hline \multirow[t]{4}{*}{ Siluriformes } & \multirow[t]{4}{*}{ Trichomycteridae } & Nematogenys inermis (Guichenot 1848) \\
\hline & & Trichomycterus areolatus (Valenciennes 1848) \\
\hline & & Trichomycterus chiltoni (Eigenmann 1927) \\
\hline & & Bullockia maldonadoi (Eigenmann 1928) \\
\hline \multirow[t]{2}{*}{ Osmeriformes } & \multirow{2}{*}{ Galaxidae } & Galaxias maculatus (Jenyns 1842) \\
\hline & & Brachygalaxias bullocki (Regan 1908) \\
\hline Mugiliformes & Mugilidae & Mugil cephalus Linnaeus 1758 \\
\hline \multirow[t]{3}{*}{ Atheriniformes } & \multirow[t]{3}{*}{ Atherinopsidae } & Odontesthes mauleanum (Steindachner 1896) \\
\hline & & Odontesthes regia (Humboldt 1821) \\
\hline & & Basilichthys microlepidotus (Jenyns 1841) \\
\hline \multirow[t]{6}{*}{ Perciformes } & \multirow[t]{2}{*}{ Percichthyidae } & Percichthys trucha (Valenciennes 1833) \\
\hline & & Percichthys melanops Girard 1855 \\
\hline & \multirow[t]{2}{*}{ Perciliidae } & Percilia irwini Eigenmann 1927 \\
\hline & & Percilia gillissi Girard 1855 \\
\hline & Eleginopsidae & Eleginops maclovinus (Valenciennes 1830) \\
\hline & Cichlidae & Cichlasoma fascetum (Jenyns 1842) \\
\hline Clupeiformes & Clupeidae & Brevoortia maculata (Valenciennes 1847) \\
\hline Cypriniformes & Cyprinidae & Carassius carassius (Linneo 1758) \\
\hline Cyprinodontiformes & Poecilidae & Gambusia holbrooki (Girard 1859) \\
\hline \multirow[t]{2}{*}{ Salmoniformes } & Salmonidae & Oncorhynchus mykiss (Smith \& Stearley 1989) \\
\hline & & Salmo trutta (Linneo 1758) \\
\hline
\end{tabular}




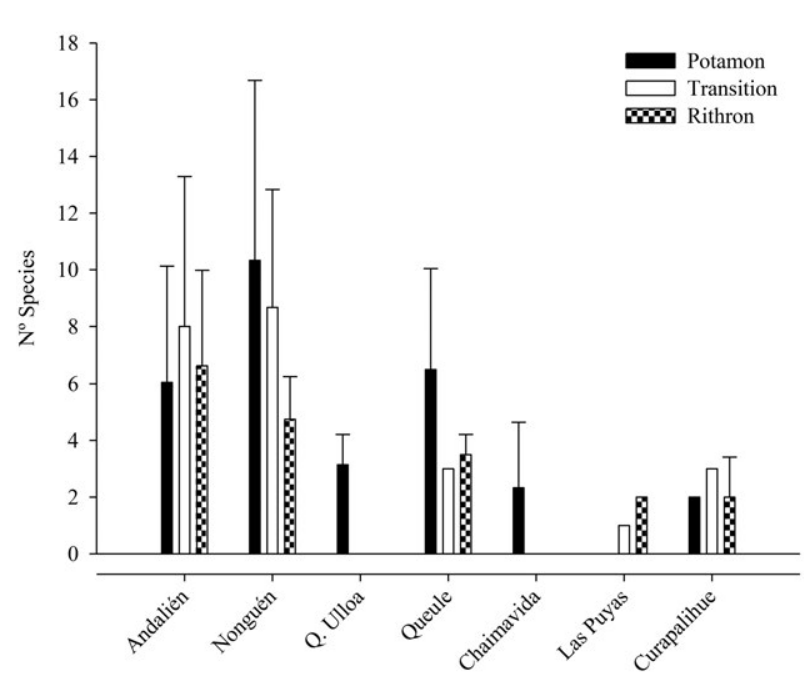

Fig. 2. Species richness determinate for each stream and fluvial zone present in the Andalién River basin.

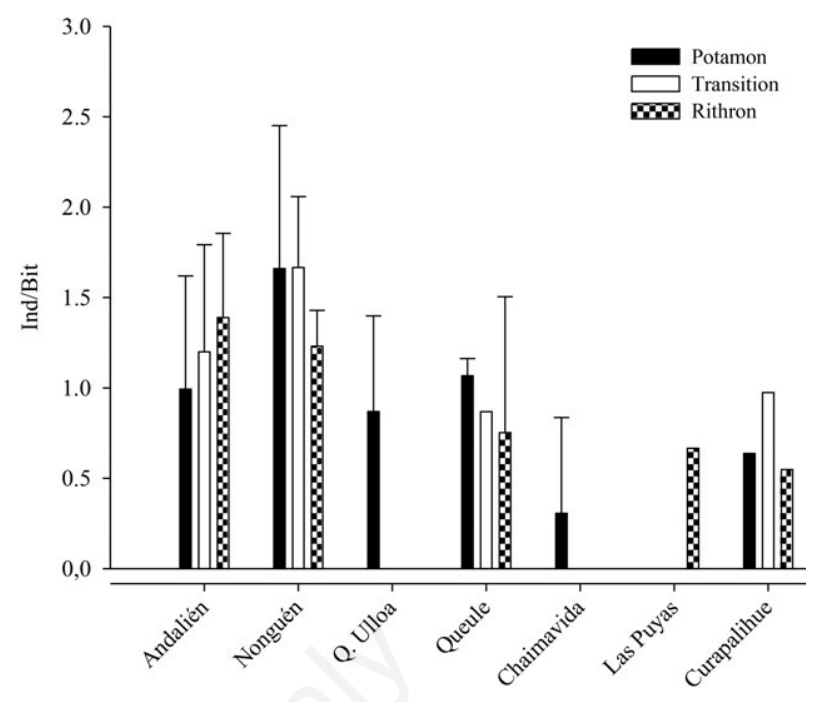

Fig. 3. Shannon-Weaver diversity index calculated for each stream and fluvial zone present in the Andalién River basin.

Tab. 3. Comparison of ecological index (Shannon diversity and richness) for each tributary and fluvial zone.

\begin{tabular}{|c|c|c|c|c|c|}
\hline \multirow[t]{2}{*}{ Index } & \multirow[t]{2}{*}{ Fluvial zone } & \multicolumn{2}{|c|}{ Kruskal-WallisDunn's post-hoc } & \multirow[b]{2}{*}{ Pairwise comparation } & \multirow[b]{2}{*}{ P-value } \\
\hline & & K-W & P-value & & \\
\hline \multirow[t]{12}{*}{ Shannon-Weaver } & \multirow[t]{5}{*}{ Potamon } & \multirow[t]{5}{*}{26.93} & \multirow[t]{5}{*}{$* * *$} & Andalién/Chaimavida & $* * *$ \\
\hline & & & & Andalién/Curapalihue local & $* *$ \\
\hline & & & & Andalién/Nonguén & $* * *$ \\
\hline & & & & Andalién/Quebrada Ulloa & $* *$ \\
\hline & & & & Andalién/Queule & $* * *$ \\
\hline & \multirow[t]{2}{*}{ Transition } & \multirow[t]{2}{*}{7.21} & \multirow[t]{2}{*}{ ns } & Curapalihue/Nonguén & $* *$ \\
\hline & & & & Nonguén/Queule & $* *$ \\
\hline & \multirow[t]{5}{*}{ Rithron } & \multirow[t]{5}{*}{11.09} & \multirow[t]{5}{*}{ ns } & Andalién/Chaimavida & $* * *$ \\
\hline & & & & Andalién/Curapalihue & $* * *$ \\
\hline & & & & Andalién/Nonguén & $* * *$ \\
\hline & & & & Andalién/Quebrada Ulloa & $* * *$ \\
\hline & & & & Andalién/Queule & $* * *$ \\
\hline \multirow[t]{15}{*}{ Richness } & \multirow[t]{5}{*}{ Potamon } & \multirow[t]{5}{*}{39.63} & \multirow[t]{5}{*}{$* * *$} & Andalién/Chaimavida & $* * *$ \\
\hline & & & & Andalién/Curapalihue & $* * *$ \\
\hline & & & & Andalién/Nonguén & $* * *$ \\
\hline & & & & Andalién/Quebrada Ulloa & $* * *$ \\
\hline & & & & Andalién/Queule & $* * *$ \\
\hline & \multirow[t]{4}{*}{ Transition } & \multirow[t]{4}{*}{8.82} & \multirow[t]{4}{*}{$*$} & Andalién/Las Puyas & $* *$ \\
\hline & & & & Nonguén/Curapalihue & $*$ \\
\hline & & & & Nonguén/Las Puyas & $*$ \\
\hline & & & & Nonguén/Queule & $*$ \\
\hline & \multirow[t]{6}{*}{ Rithron } & \multirow[t]{6}{*}{12.51} & \multirow[t]{6}{*}{$*$} & Andalién/Curapalihue local & $*$ \\
\hline & & & & Andalién/Nonguén & $*$ \\
\hline & & & & Curapalihue/Nonguén & $*$ \\
\hline & & & & Curapalihue local/Las Puyas & $*$ \\
\hline & & & & Las Puyas/Nonguén & $* *$ \\
\hline & & & & Las Puyas/Poñen & $*$ \\
\hline
\end{tabular}




\section{Spatial predictions}

For the spatial prediction, seven models were evaluated, finding the stable model that better fitted to the data of species richness and Shannon-Weaver diversity. A simple Kriging, first order, was performed exhibiting the lowest standardized mean of the prediction error according to the cross-validation test (Cruz-Cárdenas et al., 2013) (Tab. 4). The simple kriging estimate the major richness of species related to the potamon and transition zone of Nonguén stream, and the terminal stretch of Andalién, Poñen and Curapalihue streams. Meanwhile the lowest values where found in the middle stretch of Andalién and Chaimavida sub-basin (Fig. 4).

Shannon-Weaver diversity spatial prediction was performed using a simple kriging, first order, based in a Gaussian model, which described the lowest error (Tab.
4). Kriging results established the highest values (1.525 $1.905 \mathrm{bit} / \mathrm{ind})$ in the same zones that described richness predictions, but with an increment in the extension in the terminal and convergence zone of Poñen and Curapalihue streams. Low diversity values $(>0.381 \mathrm{bit} / \mathrm{ind})$ showed the

Tab. 4. Cross-validation test of mean standardization of the error prediction for the different Kriging techniques.

\begin{tabular}{|c|c|c|}
\hline \multirow[t]{2}{*}{ Kriging method } & \multicolumn{2}{|c|}{ Mean standardization error prediction } \\
\hline & Richness index & Diversity index \\
\hline Universal & $4.3 \mathrm{e}^{28} \pm 9.7 \mathrm{e}^{28}$ & $1.14 \pm 0.36$ \\
\hline Ordinary & $5.35 \pm 1.53$ & $0.61 \pm 0.04$ \\
\hline Simple & $4.59 \pm 0.51$ & $0.52 \pm 0.08$ \\
\hline
\end{tabular}

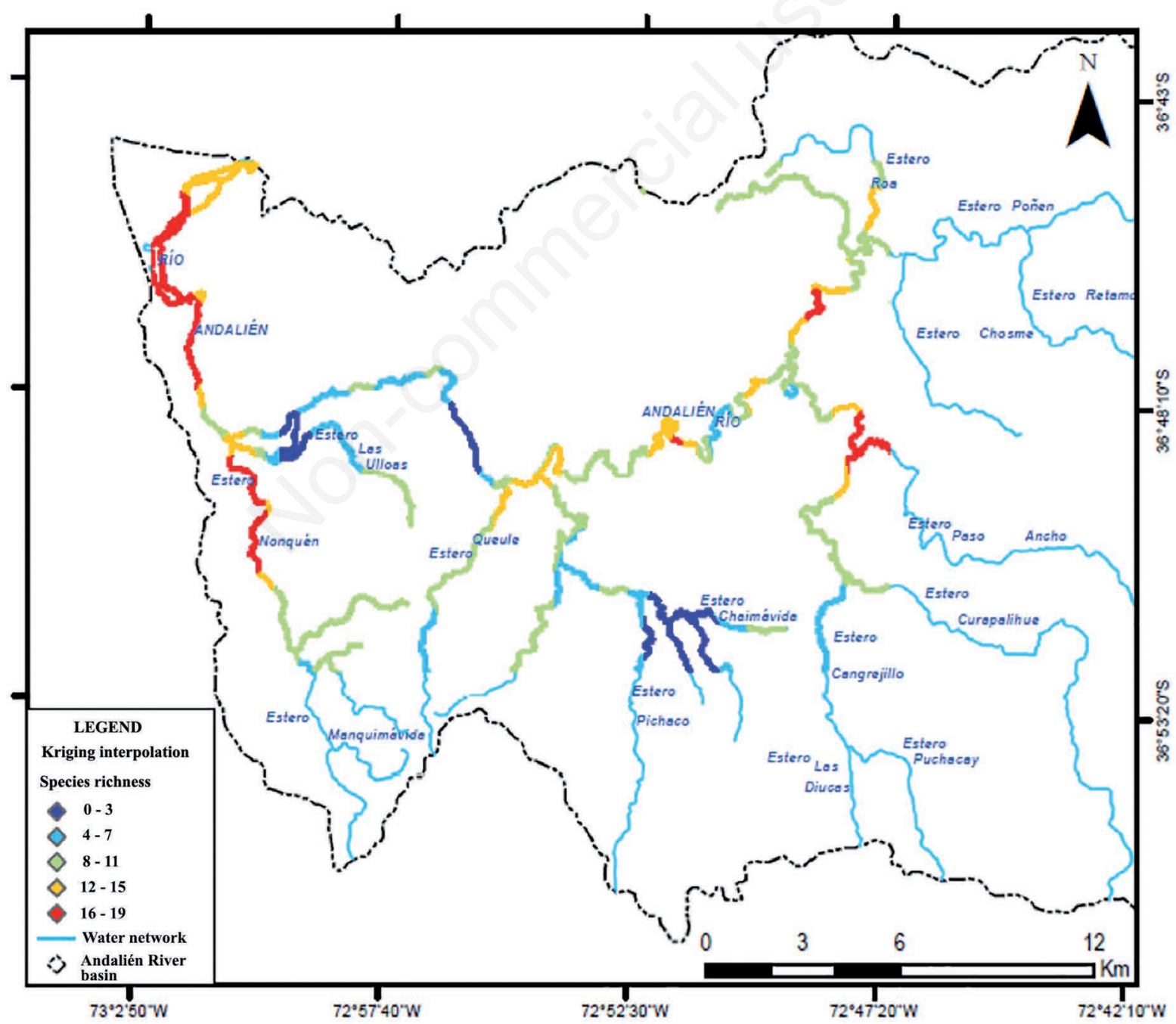

Fig. 4. Spatial prediction for species richness (fish assemblage) using simple Kriging interpolation in the Andalién River basin. 
same trend as species richness prediction map labelled principally at Chaimavida sub-basin (Fig. 5). The variographic analysis parameters obtained for the estimation of species richness and Shannon-Weaver diversity are described in Tab. 5.

\section{Spatial patterns}

Global Moran's index test revealed a clustered pattern for richness records $(\mathrm{Z}=2.247 ; \mathrm{P}=0.024)$ and ShannonWeaver diversity index $(\mathrm{Z}=3.227 ; \mathrm{P}=0.001)$. Getis-Ord Gi* spatial statistic showed a hotspot of species richness in a few points in the potamon and transition zone of Andalién and Nonguén streams (Fig. 6). While the diversity index described hotspot distribution only in the discharge of the Nonguén stream and a coldspot random distribution located near the discharge of the Nonguén stream, middle zone of Andalién and Chaimavida subbasin (Fig. 7).

\section{Environmental variables and spatial predictions}

Spatial prediction for both ecological indices seems to be related to structural variables of the basin. By a

Tab. 5. Parameters for variographics analysis for estimation of species richness and Shannon-Weaver diversity.

\begin{tabular}{lcc} 
Spatial parameters & Species richness & Shannon-Weaver diversity \\
Nugget effect & 0.343 & 0.949 \\
\hline Partial sill & 0.188 & 0.154 \\
\hline Range & 4.028 & 11.577 \\
\hline
\end{tabular}

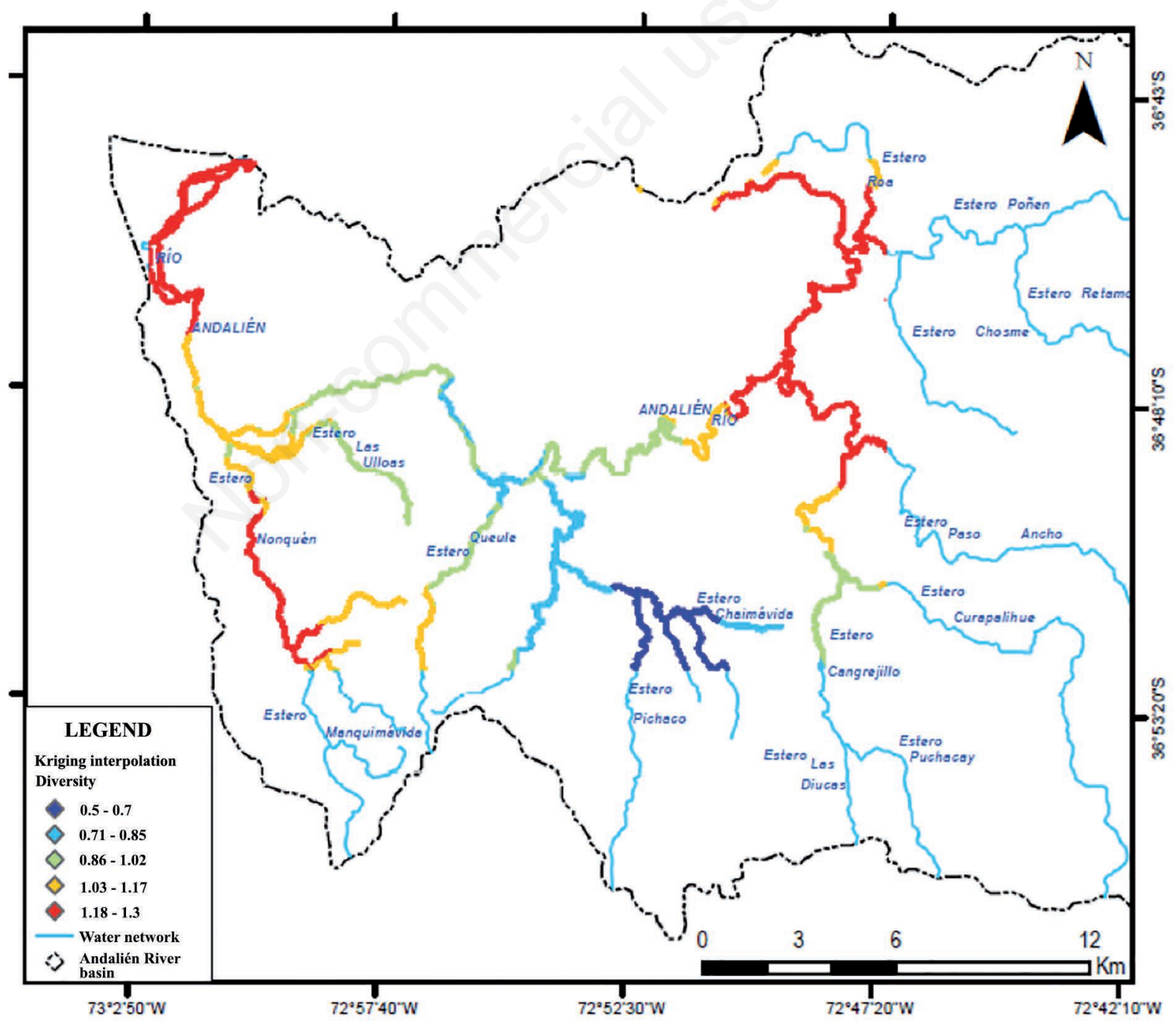

Fig. 5. Spatial prediction for Shannon-Weaver diversity index (fish assemblage) using simple in the Andalién River basin. 
multiple regression model between the both index and all the explanatory variables (structural variables, Strahler order, slope and elevation) explained less than $15 \%$ of all the variation of the fish assemblage (Tab. 6).
Showing that the predictions patterns of the ecological index were weakly explained by local scale structural variables, especially slope and elevation data which did not exhibited significant value as Strahler order showed

Tab. 6. Coefficients for structural variables related with the ecological index, results from multiple regression stepwise.

\begin{tabular}{|c|c|c|c|c|c|c|c|}
\hline \multirow[t]{2}{*}{ Ecological index } & \multirow[t]{2}{*}{ Structural variable } & \multicolumn{6}{|c|}{ GLM } \\
\hline & & Estimate & Std. Error & $\mathrm{t}$ & $\mathbf{P}$ & $R^{2}$ & $\mathrm{AIC}$ \\
\hline \multirow[t]{3}{*}{ Richness } & Elevation & $1.5 \mathrm{e}-04$ & 0.01 & -1.53 & ns & 0.04 & 345.12 \\
\hline & Strahler order & 1.18 & 0.44 & 2.67 & $* * *$ & 0.15 & 340.55 \\
\hline & Slope & $-5.0 \mathrm{e}-03$ & 0.09 & -0.06 & ns & 0.0 & 347.50 \\
\hline \multirow[t]{3}{*}{ Shannon-Weaver } & Elevation & $-6.9 \mathrm{e}-04$ & $1.5 \mathrm{e}-03$ & -0.46 & ns & 0.0 & 121.30 \\
\hline & Strahler order & 0.06 & 0.1 & 0.65 & ns & 0.01 & 124.84 \\
\hline & Slope & $7.3 e-05$ & 0.01 & 0.01 & ns & 0.0 & 121.52 \\
\hline
\end{tabular}

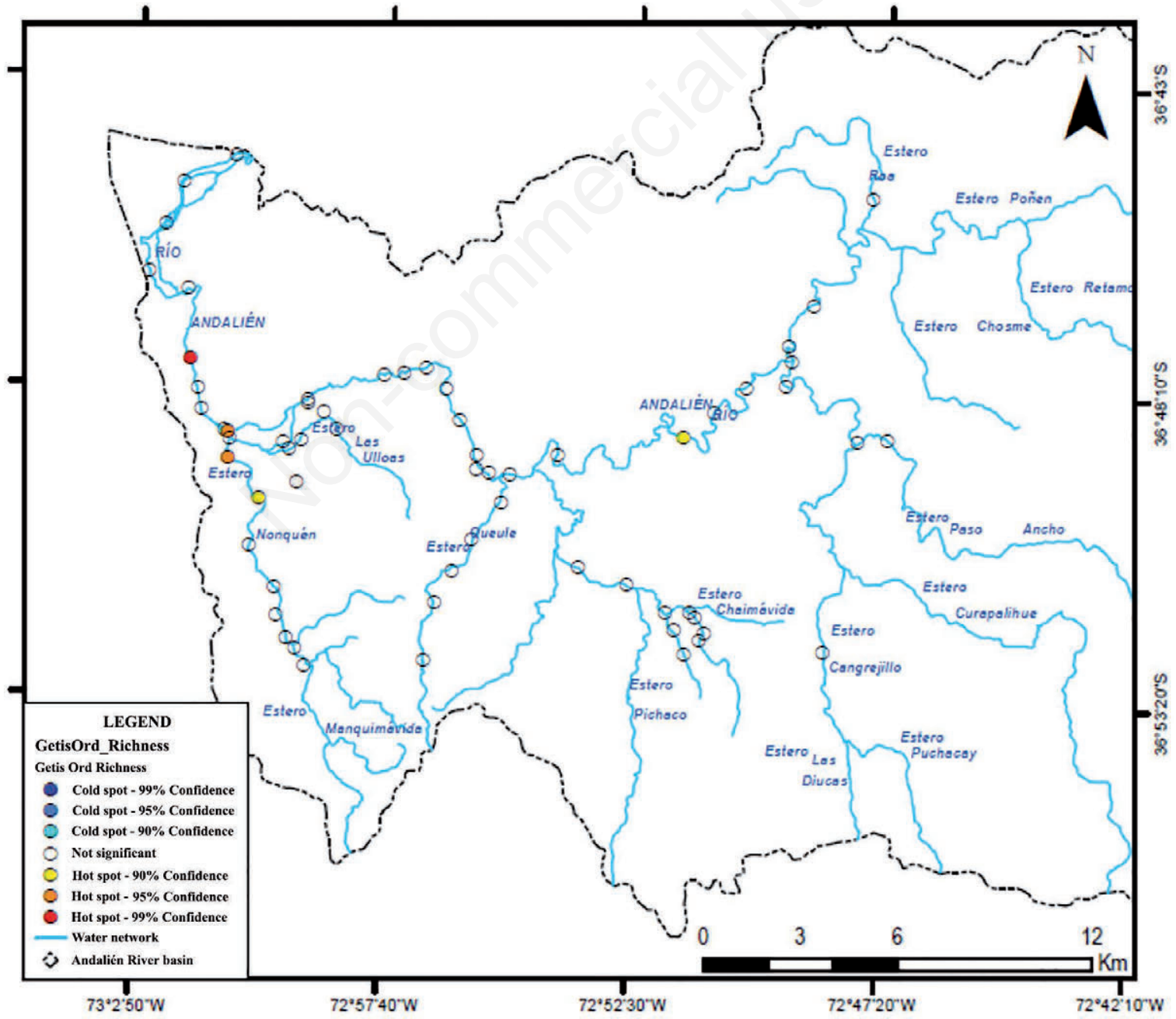

Fig. 6. Getis Ord geostatistical analysis based on species richness index for Andalién River basin. 
(Tab. 6). Nevertheless, the coefficient regression described no significant relationship between structural and ecological values.

\section{DISCUSSION}

Fish assemblages in riverine systems are described by the typical follow pattern of increasing species richness and diversity from the upstream to downstream (Vannote et al., 1980; Welcomme, 1985). Probably the majority of Chilean rivers have this zonation pattern; where exists a longitudinal gradient of richness and diversity increase in the current direction (Campos et al., 1993; Duarte et al., 1971; Habit et al., 2004; 2007), which is mainly linked to the heterogeneity of habitats and food availability (Oberdorff et al., 1993). However, this typical pattern of richness and diversity may be affected by the presence of fisheries over a relatively short time scale (Welcomme, 1985), an accumulative habitat or environmental degradation resulting from human activities (Wolter et al., 2000; Habit et al., 2005; 2006a). Andalién River basin is located in the Chilean ichthyogeographic zone, specifically in the southcentral area (Dyer, 2000) with the greatest fish diversity and endemism (Habit et al., 2006b), even when this network has a low fluvial order (4) and a small drainage area (Jaque, 1996). Our results described a fish community composed of 24 species, mostly native (Ruiz, 1993; Habit et al., 2004; 2007) and endanger conservation status (Campos et al., 1998). This important fish species concentration is explained by the great variety of habitats that this river presents (Ruiz, 1993; Habit and Victoriano, 2005) due to its markedly concave longitudinal profile (Campos et al., 1993) and the existence of some fragments of native forest preserved in the upper reaches (Habit et al.,

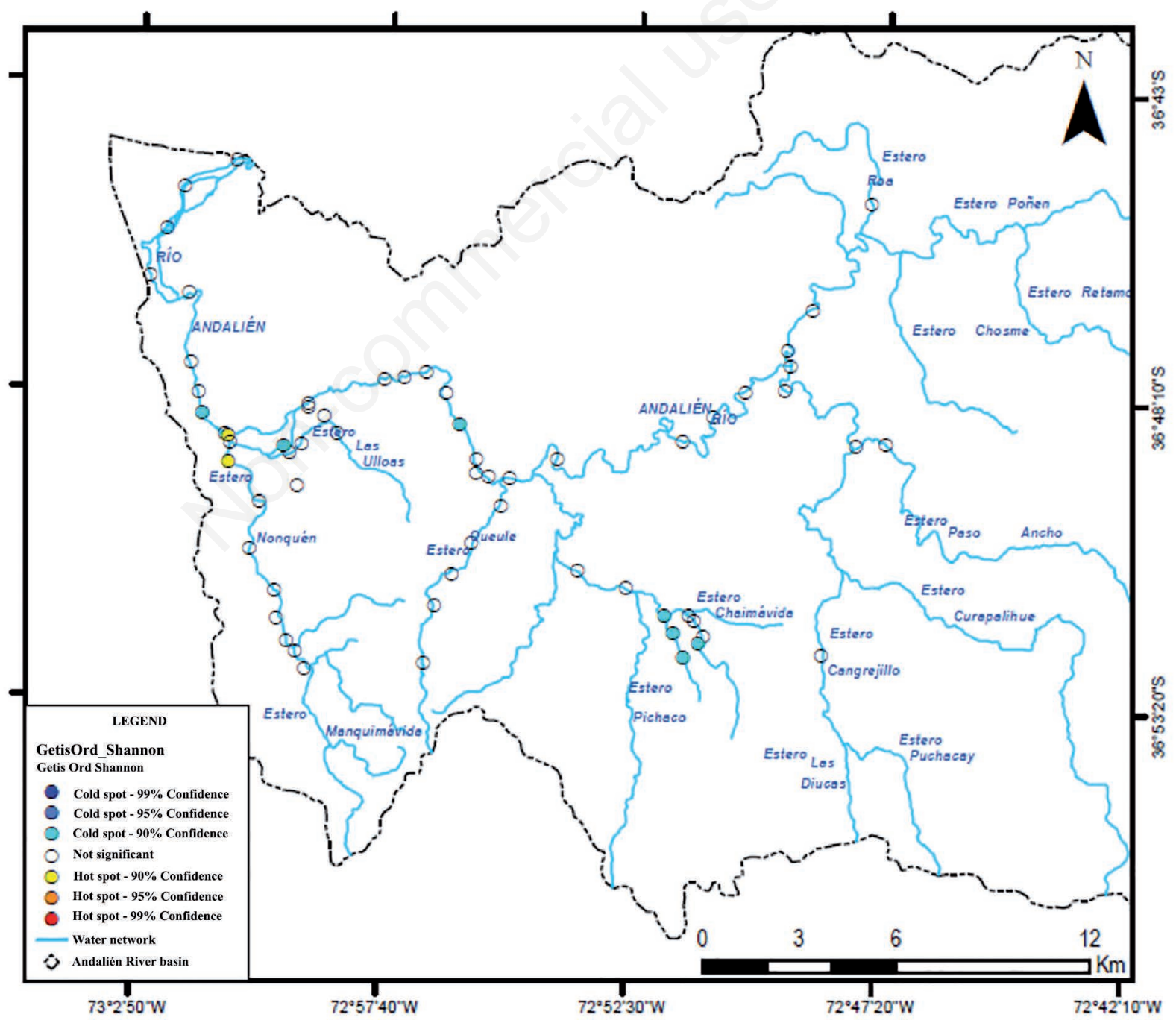

Fig. 7. Getis Ord geostatistical analysis based on Shannon-Weaver index for Andalién River basin. 
2004). However, our results described a low value of diversity at basin level, probably because our analysis considers first-order tributaries (i.e., Las Puyas, Curapalihue local), characterized by poor fish representation (Hynes, 1970) as a result of a restricted mosaic of habitats (Welcomme 1985), low trophic levels (Oberdorff et al., 1993) and the presence of natural barriers (Rahel, 2007) that difficult the colonization and occupation of these areas, especially for our native Chilean fish species that are adapted to habitats with low velocity and longitudinal gradient, and thereby restricted to lower zones (Campos et al., 1993; Vila et al., 1999).

The application of geostatistical techniques and spatial interpolation have been widely used for conservation issues (Carroll and Pearson, 1998; 2000; Williams et al., 2002; Pliscoff and Castillo, 2011) specially for research on biodiversity patterns, distribution of endemism, species turnorver rates, hotspot identification zones and alien species colonization (Bonn et al., 2002; Cruz-Cárdenas et al., 2013; Filipa et al., 2017; Hernández-Pérez et al., 2011; Lin et al., 2008, Ruíz-Luna et al., 2010; MartínezFreiria et al., 2008; Ortiz, 2013; Williams et al., 2002). This approach has allowed to obtain optimal predictions of biological variables at proximate sites where no data has been collected (Carrol and Pearson, 1998; 2000). These findings are fundamental for making decision on conservation issues and species protection actions, focusing efforts in priority sites with the highest values of biodiversity and endemism.

We developed predictive maps using the simple kriging technique that allowed us to establish areas with high fish representation and important zones for environmental conservation for the basin. Both ecological index, species richness and Shannon-Weaver diversity, showed two representative stretches. The first one, from the discharge of the Nonguén stream to the mouth of the Andalién network, and the terminal stretch of the Poñen and Curapalihue streams, possibly due to the variety of habitats of both sections. These fluvial sections should have issues of conservation and protection due to their primitive singularity and high values of endemism species (Vila et al., 1999; Dyer, 2000) specially the last stretch of the basin. But, on the contrary, they are fluvial sections subjected to channel interventions (Ortiz-Sandoval et al., 2009), alterations in water quality (Jaque, 1994) and habitat loss (Smiley and Dibble, 2008), with negative repercussions on the composition, diversity and distribution of the local ichthyofauna (Habit et al., 2005; 2007; Ortiz-Sandoval et al., 2009). This distribution pattern of the assemblage in this basin may be influenced by several factors such as: ecological issues and physical processes (Ganio et al., 2005; Hoef et al., 2006), morphology of the network (Ferreira et al., 2016; Filipa et al., 2017), physicochemical (Buisson et al., 2007) and structural variables of the basin (Ganio et al.,
2005). However, in our study structural variables showed a weak predictive power that did not allow us to explain the distribution patterns indicated in the predictive maps. Probably, it is due to the low fluctuation of elevation, slope and fluvial order that the basin presented (Jaque 1996) in relation to a basin of Andean origin (Habit and Victoriano, 2005) and to the variability that can present the data.

On the other hand, spatio-temporal variability and data independence in geostatistical analyzes are requirements that are not always met (Carroll and Pearson, 1998) and in the freshwater stream spatial environments autocorrelation is an intrinsic characteristic (Townsend, 1996; Peterson and Ver Hoef, 2010) which agrees with the results obtained with the general index of Moran in this study. In addition, through the Getis Ord index it was possible to describe a marked hotspot of species richness in the terminal stretch of the Andalién near the discharge of the Nonguén stream, and a coldspot of diversity in the rithron of the basin, specifically in the streams Las Puyas and Curapalihue local, concordant with the statistical analyzes described in this research.

\section{CONCLUSIONS}

The results of this study allow us to conclude that the application of geostatistic techniques of prediction and interpolation maps facilitate the establishment of patterns of distribution and species clustering, in this case, the fish assemblage of Andalién network, and thereby generate the bases of information to determine actions and decisions for effective conservation areas for species with endanger conservation status, especially this network which is located in a relevant ecoregion for native and endemic fish species in Chile.

\section{ACKNOWLEDGMENTS}

Reinaldo Rivera were supported by a CONICYT Doctoral Fellowship (21160866) and Doctoral Fellowship from the Dirección de Postgrado of the Universidad de Concepción; Cristián E. Hernández thanks the FONDECYT grant 1170815.

\section{REFERENCES}

Armstrong M, Renard D, Rivoirard J, Petitgas P, 1992. Geostatistics for fish survey data. Centre de Géostatistique. Ecole des Mines de Paris. Fontainebleau, France: 97 pp.

Aubry P, Debouzie D, 2000. Geostatistical estimate variance for the spatial mean in two-dimensional systematic sampling. Ecology 81:543-553.

Ayala-Pérez L, Gómez-Montes B, Ramos J, 2001. [Distribución, abundancia y parámetros poblacionales de la mojarra Diapterus rhombeus (Pisces: Gerreidae) en la Laguna de 
Términos, México].[Article in Spanish]. Rev. Biol. Trop. 49:635-642.

Ballesteros-Mejia L, Kitching I, Jetz W, Nagel P, Beck J, 2013. Mapping the biodiversity of tropical insects: species richness and inventory completeness of African sphingid moths. Global Ecol. Biogeogr. 22:586-595.

Bonn A, Rodríguez A, Gaston KJ, 2002. Threatened and endemic species: are they good indicators of patterns of biodiversity on a national scale? Ecol. Lett. 5:733-741.

Buisson L, Blanc L, Grenouillet G, 2008. Modelling stream fish species distribution in a river network: the relative effects of temperature versus physical factors. Ecol. Freshwater Fish. 17:244-257.

Campos H, Alay, Ruíz VH, Gavilán J, 1993. [Antecedentes biológicos de la fauna íctica presente en la hoya hidrográfica del río Biobio]. In: F. Faranda and O. Parra (eds.), [Evaluación de la calidad del agua y ecología del sistema limnético y fluvial del río Biobío].[Book in Spanish]. Series Monográficas Científicas EULA, Concepción, Chile.

Campos H, Dazarola G, Dyer B, Fuentes L, Gavilán J, Huaquín L, Martínez G, Meléndez R, Pequeño G, Ponce F, Ruiz VH, Siefeld W, Soto D, Vega R, Vila I, 1998. [Categorías de Conservación de peces nativos de aguas continentales de Chile].[Article in Spanish]. Boletín del Museo Nacional de Historia Natural, Santiago de Chile 47:101-122.

Carroll S, Pearson D, 1998. Spatial modeling of butterfly species richness using tiger beetles (Cicindelidae) as a bioindicator taxon. Ecol. Appl. 8:531-543.

Carroll S, Pearson D, 2000. Detecting and modeling spatial and temporal dependence in conservation biology. Conserv. Biol. 14: 1893-1897.

Clarke KR, Gorley RN, 2005. PRIMER v.6: User Manual/Tutorial. PRIMER-E Ltda., Playmouth, UK.

Cressie N, 1985. Fitting variogram models by weighted least squares. J. Int. Ass. Math. Geol. 17: 563-586.

Cressie N, 1990. The origins of kriging. Math. Geol. 22:239-252.

Cruz-Cárdenas G, Villaseñor JL, López-Mata L, Ortiz E, 2013. [Distribución espacial de la riqueza de especies de plantas vasculares en México].[Article in Spanish]. Rev. Mex. Biodiver. 84:1189-1199.

Duarte W, Feito R, Jara C, Moreno C, Orellana A, 1971. [Ictiofauna del sistema hidrográfico del río Maipo].[Article in Spanish]. Bol. Mus. Nac. Hist. Nat. Chile 32:227-268.

Dyer B, 2000. Systematic review and biogeography of the freshwater fishes of Chile. Est. Oceanol. 19:77-98.

ESRI, 2014. ArcGIS Desktop: Release 10. Environmental Systems Research Institute, Redlands.

Ferreira M, Filipe A, Bardos D, Magalhaes M, Beja P, 2016. Modeling stream fish distributions using interval-censored detection times. Ecol. Evol. 6:5530-5541.

Filipa A, Quaglietta L, Ferreira M, Magalahaes M, Beja P, 2017. Geostatistical distribution modelling of two invasive crayfish across dendritic stream networks. Biol. Invasions. 19:2899-2912.

Fortin M, Dale M, 2005. Spatial analysis: a guide for ecologists. Cambridge University Press, Cambridge.

Gallardo A, 2006. [Geostadística].[Article in Spanish]. Ecosistemas 15:48-58.

Ganio L, Torgersen E, Gresswell R, 2005. A geostatistical approach for describing spatial pattern in stream networks. Front. Ecol. Environ. 3:138-144.

Getis A, Ord J, 1992. The analysis of spatial association by use of distance statistics. Geogr. Anal. 4:189-206.

Growns I, Gehrke P, Astles K, Pollard D, 2003. A comparison of fish assemblage associated with different riparian vegetation types in the Hawkesbury-Nepean River system. Fisheries Manag. Ecol. 10:209-220.

Goodchild M, 1987. A spatial analytical perspective on geographical information systems. Int. J. Geogr. Inf. Sy. $1: 327-334$.

Habit E, Victoriano P, Rodríguez-Ruíz A, 2004. [Variaciones espacio-temporales del ensamble de peces de un Sistema fluvial de bajo orden del centro-sur de Chile].[Article in Spanish]. Rev. Chil. Hist. Nat. 76:3-14.

Habit E and Victoriano P, 2005. [Peces de agua dulce de la Cordillera de la Costa]. In: C. Smith-Ramírez, J. Armesto and C. Valdovinos (eds.), [Biodiversidad y Ecología de la Cordillera de la Costa de Chile].[Book in Spanish]. ditorial Universitaria, Santiago.

Habit E, Dyer B, Vila I, 2006a. [Estado de conocimiento de los peces dulceacuícolas de Chile].[Article in Spanish]. Gayana 70:100-113.

Habit E, Belk M, Tuckfield C, Parra O, 2006b. Response of the fish community to human-induced changes in the Biobio River in Chile. Freshwater Biol. 51: 1-11.

Habit E, Belk M, Victoriano P, Jaque E, 2007. Spatio-temporal distribution patterns and conservation of fish assemblage in a Chilean coastal river. Biodivers. Conserv. 16:3179-3191.

Hammer O, Harper D, Ryan P, 2001. Past: Paleontological statistics software package for education and data analysis. Paleontología Electrónica 4:1-9.

Hemyari P, Nofziger D, 1987. Analytical solution for punctual kriging in one dimension. Soil Sci. Soc. Am. J. 51:268-269.

Hernández-Cervantes O, Sentíes A, Tapia F, Dreckmann K, Díaz L, 2014. [Distribución espacial de la riqueza de especies del género Laurencia (Ceramiales: Rhodophyta)].[Article in Spanish]. Proceedings 10th Cong. de Ficología de Latinoamérica y El Caribe.

Hernández-Pérez E, González-Espinosa M, Trejo I, Bonfil C, 2011. [Distribución del género Busera en el estado de Morelos, México y su relación con el clima].[Article in Spanish]. Rev. Mex. Biodiver. 82:964-976.

Humpl M, Pivnicka K, 2006. Fish assemblages as influenced by environmental factors in streams in protected areas of the Czech Republic. Ecol. Freshwater Fish 15:96-103.

Isaaks E, Srivastava R, 1989. An introduction to applied geostatistics. Oxford University Press, New York: 592 pp.

Jaque E, 1996. [Análisis integrado de los sistemas naturales de la Cuenca del río Andalién: bases para la planificación ecológica del territorio de la cuenca].[Thesis in Spanish]. Universidad de Concepción.

Jaque E, 2008. [Geomorfología de la Cuenca del río Andalién, Chile].[Article in Spanish]. Rev. Geogr. 143:97-116.

Kravchenko A, Bullock D, 1999. A comparative study of interpolation methods for mapping soil properties. Agron. J. 91:393-400.

Kreft H, Jetz W, 2007. Global patterns and determinants of vascular plant diversity. P. of the Natl. Acad. Sci. 104:5925-5930.

Krige D, 1951. A statistical approach to some basic mine 
valuation problems on the Witwatersrand. J. S. Afr. I. Min. Metall. 52:119-139.

Kruskal W, Wallis W, 1952. Use of ranks in one-criterion variance analysis. J. Am. Stat. Ass. 47:583-621.

Legendre P, 1993. Spatial autocorrelation: Trouble or new paradigm? Ecology 74:1659-1673.

Lin Y, Ming-Sheng Y, Dong-Po P, Yung-Chieh W, 2008. Geostatistical approaches and optimal additional sampling schemes for spatial patterns and future sampling of bird diversity. Global Ecol. Biogeogr. 17:175-188.

Northcote T, 1988. Fish in the structure and function of freshwater ecosystems: A top-down view. Can. J. Fish. Aquat. Sci. 45:361-379.

Marchetti M and Moyle P, 2001. Effects of flow regime on fish assemblages in a regulated California stream. Ecol. Appl. 11:530-539.

Martínez A, 2015. [Análisis espacial de la fauna silvestre en el norte del municipio de Guerrero Coahuila].[PhD Thesis in Spanish]. Universidad Autónoma Agraria Antonio Narro, Saltillo.

Martínez-Freiría F, Santos X, Pleguezuelos J, Lizana M, Brito J, 2009. Geographical patterns of morphological variation and environmental correlates in contact zones: a multi-scale approach using two Mediterranean vipers. J. Zool. Syst. Evol. Res. 47:357-367.

Martínez-Freiría F, Brito J, 2013. Integrating classical and spatial multivariate analyses for assessing morphological variability in the endemic Iberian viper Vipera seoanei. J. Zool. Syst. Evol. Res. 51:122-131.

Matheron G, 1963. Principles of geostatistics. Econ. Geol. 58:1246-266.

Matthews W, 1998. Patterns in freshwater fish ecology. Chapman and Hall, New York: 756 pp.

Mitchell A, 2005. [La Guía de Esri para el análisis SIG].[Book in Spanish]. Esri Press.

Monestiez P, Dubroca L, Bonni E, Durbec J, Guinet C, 2006. Geostatistical modelling of spatial distribution of Balaenoptera physalus in the Northwestern Mediterranean Sea from sparse cout data and heterogeneous observation efforts. Ecol. Modell. 193:615-628.

Moran P, 1950. Notes on continuous stochastic phenomena. Biometrika 37:17-23.

Oberdorff T, Gilbert E, Lucchetta J, 1993. Patterns of fish species richness in the Seine River basin, France. Hidrobiología. 259: 157-167.

Ord K, 1983. Kriging, p. 411-413. In: S. Kotz and N. Johnson (eds.), Encyclopedia of statistical sciences. Wiley, New York.

Oliver M, Webster R, 1990. Kriging: a method of interpolation for geographical information systems. Int. J. Geogr. Inform. Sys. 4:313-332.

Orme C, Davies R, Burgess M, Eigenbrod F, Pickup N, Olson V, Stattersfield A, Bettett P, Blackburn T, Gaston K, Owens I, 2005. Global hotspot of species richness is not congruent with endemism or threat. Nature 436:1016-1019.

Ortiz A, 2013. [Efecto de la variabilidad ambiental interanual en la distribución y abundancia de larvas de dorado (Coryphaena spp.) en el pacífico central oriental].[PhD Thesis in Spanish]. Centro Interdisciplinario de Ciencias Marinas, Instituto Politécnico Nacional, La Paz.

Parkos J, Santucci V, Wahl D, 2011. Effects of adult common carp (Cyprinus carpio) on multiple trophic levels in shallow mesocosms. Can. J. Fish. Aquat. Sci. 60:182-192.

Quinn GP, Keough MJ, 2002. Experimental design and data analysis for biologists. Cambridge University Press, Cambridge: $556 \mathrm{pp}$.

Petitgas P, 1993. Use of a disjunctive kriging to model areas of high pelagic fish density in acoustuc fisheries surveys. Aquat. Liv. Res. 6:201-209.

Pliscoff P, Castillo T, 2011. [Modelación de la distribución de especies y ecosistemas en el tiempo y en el espacio: una revisión de las nuevas herramientas y enfoques disponibles]. [Article in Spanish]. Rev. Geogr. Norte Gr. 48:61-79.

Rahel F, 2007. Biogeographic barriers, connectivity and homogenization of freshwater faunas: it's a small world after all. Freshwater Biol. 56 696-710.

Rangel T, Diniz-Filho J, Bini L, 2006. Towards an integrated computational tool for spatial analysis in macroecology and biogeography. Global Ecol. Biogeogr. 15:321-327.

Ramírez L, Falcón V, 2015. [Autocorrelación espacial: Analogías y diferencias entre el índice de Moran y el índice Getis y Ord. Aplicaciones con indicadores de acceso al agua en el norte argentino].[Article in Spanish]. Proceedings 5th Congr. Nacional de Geografía de Universidades Públicas, Neuquén.

Reeves M, Medley K, Pinkney A, Holyoak M, Johnson P, Lannoo M, 2013. Localized hotspots drive continental geography of abnormal amphibians on US Wildlife Refuges. PLoS One 8): e77467.

Rivoirard J, Simmonds K, Foote G, Fernandes P, Bez N, 2000. Geostatistics for estimating fish abundance. Blackwell Science, London: 206 pp.

Robertson G, 1987. Geostatistics in ecology: Interpolating with known variance. Ecology 68:744-748.

Ruíz VH, 1993. [Ictiofauna del Río Andalién (Concepción, Chile)].[Article in Spanish]. Gayana Zool. 57:109-278.

Ruiz-Luna A, Meraz-Sánchez R, Madrid-Vera J, 2010. Abundance distribution patterns of commercial shrimp off northwestern Mexico modeled with geographic information systems. Cien. Mar. 36:107-120.

Smiley P, Dibble E, 2008. Influence of spatial resolution on assessing channelization impacts on fish and macroinvertebrate communities in a warmwater stream in the southeastern United States. Environ. Monitor. Assess. 138:17-29.

Vannote R, Minshall G, Cummings K, Sedell J, Cushing C, 1980. The river continuum concept. Can. J. Fish Aquat. Sci. 37:130-137.

Ver Hoef J, Petersen E, Theobald D, 2006. Spatial statistical models that use flow and stream distance. Environ. Ecol. Stat. 13:449-464.

Vila I, Fuentes L, Contreras M, 1999. [Peces límnicos de Chile].[Article in Spanish]. Bol. Mus. Nac. Hist. Natural Chile 48:61-75.

Welcomme R, 1985. River fisheries. FAO Fisheries Technical Paper 262. FAO, Rome: 339 pp.

William O, Margules C, Hilbert D, 2002. Data requirements and data sources for biodiversity priority area selection. J. Biosci. 27:327-338.

Wolter C, Minow J, Villnskas A, Grosch U, 2000. Long-term effects of human influence on fish community structural and fisheries in Berlin waters: An urban water system. Fisheries Manag. Ecol. 7:97-104. 